International Review of Social History 45 (2000), pp. 385-407

(C) 2000 Internationaal Instituut voor Sociale Geschiedenis

\title{
Self-Help Criminality as Resistance?: Currency Counterfeiting in Colonial Nigeria*
}

\author{
Ayodeji Olukoju
}

Summary: This essay examines the counterfeiting and uttering of British Imperial coinage in interwar Nigeria, and the response of the colonial state. In particular, it establishes a connection between criminality and resistance to European colonialism in Africa. In this regard, it contextualizes the preponderant involvement in the counterfeiting saga of the Ijebu, a subgroup of the Yoruba nationality in southwestern Nigeria. Though other considerations were involved, the preponderance of the Ijebu in making what was called "Ijebu money" illustrates how self-help criminality was both a means of accumulation and a veritable form of resistance to colonial rule. Following their military defeat in 1892 and their subsequent alienation from British rule, this criminal activity represented resistance by other means. The point must be stressed, however, that not all Ijebu were counterfeiters, and all counterfeiters were not Ijebu, and that the counterfeiters were no "heroic criminals", who shared their loot with the poor.

\section{INTRODUCTION}

The theme of protest and resistance has received considerable attention in the literature on the European colonization of Africa. As might be expected, much emphasis has been placed on overt political acts such as armed revolts. "Resistance studies", it has been noted, "insist on the importance of politics and emphasise the element of political struggle, 'now hidden, now open', that is so important a feature of life in all social formations where rulers stand apart from their subjects." ${ }^{\prime 2}$ Yet, it is important to point

\footnotetext{
* A version of this paper was presented at the West Africa Seminar, University College, London in November 1998 while the author was Chapman Fellow, Institute of Commonwealth Studies, and Leventis Fellow, SOAS, University of London. He acknowledges the research assistance of Lanre Davies (Ogun State University) in the collection of oral evidence, and the comments of Professor Murray Last, organizer of the West Africa Seminar, and other participants; those of the participants in the staff and postgraduate seminar of the Department of History, University of Lagos, as well as the Editors and referees of this journal, towards improving the quality of the essay.

I. See, for example, T.O. Ranger, Revolt in Southern Rhodesia I896-7: A Study in African Resistance (London, 1967); and Michael Crowder (ed.), West African Resistance: The Military Response to Colonial Occupation (London, 197I).

2. Donald Crummey, "Introduction: 'The great beast", in Donald Crummey (ed.), Banditry, Rebellion and Social Protest in Africa (London, 1986), pp. 2-3.
} 
out that while protest entails "a higher degree of vocalisation [...], resistance may appear mute, and stealth may be one of its essential features". ${ }^{3}$ This clarification is crucial to understanding the theme of "crime as a dimension of resistance and social protest", ${ }^{4}$ which this study seeks to explore. Engels had declared that theft was "the most primitive form of protest". ${ }^{5}$ Crummey elaborated this by asserting that crime "is inherently a form of protest, since it violates the law" ${ }^{6}$ This is amply demonstrated by this case study of currency counterfeiting in colonial Nigeria.

The subject of currency counterfeiting in Nigeria has been broached by an earlier study which set out to "explore currency forgery [...] as yet another aspect of the problems of new money in colonial Nigeria". ${ }^{7}$ In addition to the limitation of its objective, that study raised issues which require clarification, refutation and elaboration. A contentious point is the role played by the Ijebu, an enterprising and pace-setting subgroup of the Yoruba nationality of western Nigeria, in the counterfeiting saga. A scholar noted that it was among the Ijebu that "this business was most prevalent". ${ }^{8}$ The aforementioned study had ascribed Ijebu prominence to their proximity to the coast and their renowned business acumen. ${ }^{9}$ This essay rather argues that the preponderant involvement of the Ijebu in this matter demonstrates how self-help criminality served as both a source of accumulation and an expression of alienation from, and resistance to, the colonial order.

The Ijebu Kingdom had been one of the leading Yoruba states in the nineteenth century and played a key role in the civil wars that raged in Yorubaland between 1877 and $1886 .{ }^{\circ}$ As a middleman state between the warring states (Ibadan versus the Ekiti Parapo Confederacy) and the coast, it controlled the flow of trade, particularly in arms, and refused British traders based in Lagos free movement through its territory. The Ijebu opposition to "free trade" as defined and demanded by the British and, to a lesser extent, the entry of Christian missionaries, provided the pretext for the British invasion and defeat of the Ijebu Kingdom in 1892.

In the aftermath of this crushing defeat, the Ijebu were compelled to operate an "open door" policy towards British traders and missionaries. They quickly adapted by embracing Christianity and Western education but, as their involvement in currency counterfeiting reveals, they remained

3. Ibid., p. Io.

4. Ibid., p. 4.

5. Ibid., p. 3 .

6. Ibid.

7. Toyin Falola, “'Manufacturing Trouble': Currency Forgery in Colonial Southwestern Nigeria”, African Economic History, 25 (1997), p. I22.

8. Kemi Rotimi, "The Ijebu and the Police in Colonial Nigeria before 1940", Ife Journal of History, 2 (1995), p. IO2.

9. Falola, "Currency Forgery", p. I3I.

IO. Details in E.A. Ayandele, The Ijebu of Yorubaland, I850-1950: Politics, Economy and Society (Ibadan, 1992). 
alienated from, and hostile to, the new order. Their commercial activities, of which currency counterfeiting was only a seamy side, were intensified as the colonial economy evolved.

\section{THE EVOLUTION OF THE NIGERIAN COLONIAL ECONOMY AND THE UPSURGE OF CURRENCY COUNTERFEITING}

British rule had been established over much of Nigeria by 1906 and stable administration had been set up by 19I4. ${ }^{\text {II }}$ This entailed the provision of physical and fiscal infrastructure - commercial banks, railway lines, roads, harbours, courts and an imperial currency system - to make good the colonial occupation. ${ }^{12}$ By the end of the First World War, imperial currency notes in denominations of $£_{\mathrm{I}}$, IO shillings and 2 shillings, and silver, alloy and nickel coins of lower denominations dominated circulation, and soon completely supplanted precolonial non-British currencies. ${ }^{13}$

There were, however, crises in the currency system, largely on account of periodic shortages which the colonial government attributed to the African's alleged propensity to hoard or melt silver coins into ornaments. ${ }^{\mathrm{I}}$ Currency notes were, therefore, introduced as a solution but the colonial subjects rejected or discounted them for coins. It was in the midst of the currency crisis of the post-First-World-War years that a wave of currency counterfeiting hit Nigeria, particularly the western provinces contiguous to Lagos, the economic hub and chief port of Nigeria. To be sure, cases of currency counterfeiting had been reported in the prewar years. In 1906, for example, the Resident of Ilorin Province in the southern part of the Northern Nigerian Protectorate reported that, "numerous complaints are coming in of Lagos men attending the evening markets and palming off in the dark counterfeit coins on the sellers" ${ }^{15}$ Between I9IO and 19I2, there were complaints that counterfeiters based in southern Nigeria had introduced "a large number of counterfeit coins" into the northern Nigerian districts which

II. Obaro Ikime (ed.), Groundwork of Nigerian History (Ibadan, 1980), among others, treats aspects of this theme.

I2. R. Olufemi Ekundare, Economic History of Nigeria I860-1960 (London, 1973); A.G. Hopkins, An Economic History of West Africa (London, 1975); and Toyin Falola (ed.), Britain and Nigeria: Exploitation or Development? (London, 1987).

I3. A.G. Hopkins, "The Currency Revolution in Southwest Nigeria in the Late Nineteenth Century", Journal of the Historical Society of Nigeria, 3 (1966), pp. 47I-483; and Walter Ofonagoro, "From Traditional to British Currency in Southern Nigeria: Analysis of a Currency Revolution, I880-1948", Journal of Economic History, 39 (1979), pp. 623-654.

I4. Ayodeji Olukoju, "Nigeria's Colonial Government, Commercial Banks and the Currency Crisis of 1916-1920", International Journal of African Historical Studies, 30 (1997), pp. 277-298.

I5. National Archives of Nigeria, Kaduna (NAK) Secretary, Northern Provinces (SNP) 6/2/II7/ 1906, "Counterfeit coinage [...]", extract from Report No. 32 for quarter ending 3I March 1906 by Dr Paul Dwyer, Resident, Ilorin Province, para. 5. 
adjoined southern Nigeria. ${ }^{16}$ Despite arrests and the conviction of counterfeiters, the illicit activity continued unabated. The volume of the traffic and the incidence of counterfeiting increased phenomenally in the early I920s.

By far the leading centre of the illicit activity was Ijebu Province, contiguous to Lagos, though there were reports of counterfeiting in Oyo, Ondo and Benin provinces to the east. The prominence of the Ijebu soon became legendary, to the point that, by the late I920s, counterfeit coinage was known in northern and southern Nigeria as "Ijebu-Ode money". ${ }^{17}$ Till today, other Yoruba refer to counterfeits as "owo Ijebu" ("Ijebu money"). ${ }^{18}$ This might reflect some prejudice but is not entirely a product of ethnic stereotyping.

By I92I, colonial officials already knew the particular Ijebu towns noted for currency counterfeiting and even the number of its perpetrators. "So far as is known", the Resident of Ijebu Province reported, "there were at least five coiners in Ijebu-Ode, one at Iperu, one if not more at Ijebu-Igbo, and one at Okun, but owing to the simplicity of the method adopted it is not unlikely that there are others who have so far escaped detection." ${ }^{\text {'9 }}$ Ijebu coiners also operated outside their homeland. When a counterfeiting ring was broken up at Ilesha in Oyo Province, a local colonial official commented that: "It seems probable that one Ijebu man was also concerned in the making of the counterfeit coins." ${ }^{20}$ Significantly, while his four local accomplices were apprehended, the Ijebu suspect escaped!

Although the foregoing has highlighted the preponderance of Ijebu involvement in the counterfeiting of imperial coinage in post-First-WorldWar Nigeria, it is fair to stress that other Nigerian groups participated in the illicit activity. But the Ijebu clearly dominated the business, and it is therefore important to contextualize their involvement. Meanwhile, some attention will be devoted to the technology of counterfeiting, the organization of uttering, and the response of the colonial authorities in the following sections.

I6. NAK SNP 17/2 13258, "Counterfeit Coins", Acting Resident, Kabba Province to SNP, Zungeru, 24 September I9I2.

I7. National Archives of Nigeria, Ibadan (NAI) CSO 26/I/03447, "Counterfeit Coins", Kabba Province [...], Intelligence Report for quarter ending, 30 September 1929.

I8. The association of the Ijebu with currency counterfeiting is vividly expressed in the Yoruba saying: "Owo kii tan lowo Ijebu; kanran k'owo tan lowo Ijebu, a ya l'agbede, a lo ro'mii di" ("An Ijebu is never short of cash for he would simply mint his own coins")! My source is Dimeji Ajikobi, an expert on Yoruba culture, Lagos, January 2000.

I9. NAI CSO 20/9 NC75/1921, "Counterfeiting of Coinage at Ijebu-Ode", Acting Resident to Chief Secretary to the Government (CSG), Lagos, 3 April I92I.

20. NAI OyoProf I 1592, vol. I, "Counterfeit Coinage: Correspondence re", Assistant District Officer (DO), Ilesha to Resident, Oyo Province, I8 May 1936. 


\section{THE TECHNOLOGY AND ORGANIZATION OF CURRENCY COUNTERFEITING}

By its nature as a criminal act, counterfeiting was a clandestine activity that was necessarily small scale and secretive. ${ }^{2 \mathrm{I}}$ As in every other occupation, there was also a system of apprenticeship. One suspect admitted that he had learnt counterfeiting "about five months ago from an Isobo (that is, Urhobo, a non-Yoruba) at a farm on the lagoon side" beyond Atijere, coastal Ondo Province. $^{22}$ When a coining ring comprising one Maikaka, a "responsible official" of the Katsina Native Administration (NA) in northern Nigeria and his southern Nigerian accomplices, described as "professional coiners", was broken up, the police were shocked to discover that they "even had an "apprentice" ${ }^{23}$ Counterfeiters had to be highly mobile to evade detection. They carried out their operations not only in the most inaccessible places, usually in out-of-the-way locations, but also in towns, as revealed by the reports of arrests. ${ }^{24}$ As an example of the former, the Waterside area of the Ijebu Province provided a haven for counterfeiters. The Commissioner of Police stated, in a report of November 1936, that:

There is every reason to believe that a considerable number of persons in that area are engaged in this type of work. It is a difficult area to operate in owing to the fact that many of the people live in camps in thick bush and it is necessary to make special arrangements for a launch before the place can be visited. As soon as a launch is seen approaching news is passed rapidly all over the district and the people living in the camps lock their doors and run into the bush where they remain until the Police have left. In addition a fair proportion of the inhabitants are Sobos who are quite ready to put up strong resistance which renders it inadvisable to send small parties of Police in plain clothes to undertake the arrest of the offenders as is done in other parts of the Province. ${ }^{25}$

Hence, despite occasional arrests, the business continued unabated and assumed alarming proportions during the interwar years.

The tools and materials used for counterfeiting coins were essentially those employed by artisans like photographers and goldsmiths. Among the

2I. A study of a similar clandestine activity is Ayodeji Olukoju, "Prohibition and Paternalism: The State and the Clandestine Liquor Traffic in Northern Nigeria, c. I898-1918”, International Journal of African Historical Studies, 24 (1991), pp. 349-368.

22. NAI IjeProf 2 C.I2, vol. I "(I) Counterfeiting (2) Counterfeit Coining”, Rex vs Salami Temiyemi, Confid. I/1926.

23. SNP 17/2 13258, Resident, Katsina to SNP, Kaduna, is April 1938.

24. For arrests in towns (Ibadan, Ilesha, Ijebu-Ode and Lagos), see Nigerian Pioneer, I7 October 1924; NAI CSO 20/9 NC 75/192I, "Counterfeiting of Coinage at Ijebu-Ode", and NAI Oyo Prof I I592, vols. I and 2, "Counterfeit Coinage: Correspondence re", especially, enc. in A.V.D. Ince, Assistant Commissioner of Police (ACP), Oyo-Ondo Province to IGP, Lagos, I3 June 1936. See also, Falola, "Currency Forgery", pp. I25-126, Table 2.

25. NAI IjeProf 2 C.I2, vol. 3, Commissioner of Police (CP) to Resident, Ijebu Province, 28 November 1936. 
exhibits impounded by the police from convicted counterfeiters were "chloride of gold", said to have been used for photographic purposes; brass; alloy copper; borax powder; and moulds of various types. ${ }^{26}$ These were all foreign products obtained in several ways. First, by legitimate importation made by artisans, like photographers and goldsmiths, who ordinarily used them. A report of I92I showed that the metal rods found in the possession of some counterfeiters had been bought from a Syrian in Lagos. ${ }^{27}$ The Inspector General of Police reported in December 1929 that the "principal ingredient in the manufacture of counterfeit coin [...] [was] brass of which alloy there is a large importation into the country in the form of trays and other vessels" ${ }^{28}$ Second, they were ordered by post. In this connection, police in the I930s intercepted registered parcels containing materials ordered from Germany. In a particular case, the firm of J. Morin and Company of Hamburg had been requested to supply a printing press "capable of producing West African Currency Notes". ${ }^{29}$ In 1935 alone, there were several reports of "intercepted letters to America or Germany requesting the printing of [...] spurious currency"..$^{30}$ Third, local French coinage was melted down and moulded into Nigerian coinage. As the export of French coinage was prohibited, this was smuggled into Nigeria in "occasional small quantities" ${ }^{31}$

Having imported these items, the counterfeiters went to work making, and also sometimes importing, moulds. During the interwar years, three types of moulds were used to counterfeit coins. The first type was made of material from fish, and its use was described in the following way: "solder mixed with nickel [...] melted down in a small crucible [...] [was] poured in between two bits of cuttle fish, on which the impression of the coin [...] [had] been made" ${ }^{32}$ A later, and fuller, account stated that:

[...] some dry fish substance (whose proper name was unknown) [...] is collected. A good coin, new if possible, is placed on top of a peice $[s i c]$ of this substance, and another is placed on the coin. Both are pressed closely together with the result that there remains an impression of both the obverse and reverse sides of the coin. Both ends of the pulpy substance are then cut off. What is left is tied together

26. NAI IjeProf 2 C.I2, vol. I, Acting Resident, Ijebu Province to Secretary, Southern Provinces (SSP) Enugu, 3 April 192I; C.W. Duncan, Inspector General of Police, Lagos (IGP) to Treasurer, Lagos, 9 December 1929.

27. Ibid., Confid. I/ı226: Rex vs (i) Sani Owuseni (ii) Awonuyi; Report by Acting District Officer, Ijebu-Ode, 23 April 1926. This writer could not find any documentation of direct Levantine involvement in this business. A study of a group of Levantines in this region is Toyin Falola, "Lebanese Traders in Southwestern Nigeria, 1900-1960", African Affairs, 89 (1990), pp. 523-553. 28. NAI Ije Prof 2 C.I2, vol. I, IGP to Treasurer, 9 December 1929.

29. NAI CSO 26/I 03447, IGP to CSG, 28 September 1934. Cf. OyoProf I I592, vol. I, District Officer (DO), Ife/Ilesha Division to Resident, Oyo Province, 22 June 1936.

30. NAI IjeProf 2 C.I2, vol. 2, Acting Resident, Ijebu Province to SSP, Enugu, 22 September I935.

31. NAI IjeProf 2 C.I2, vol. I, IGP to Treasurer, 9 December 1929.

32. NAK SNP 17/2 I3258, IGP's minute, 26 November 1912. 
closely, and a hole is bored at one end. A metal which is labelled "half and half" is then melted in a small crucible and poured through the hole into this rather primitive die. When the metal has cooled the die is opened and the coin is taken out. Any roughness is afterwards removed by a blow pipe, and a milled edge is given by means of a long steel file. ${ }^{33}$

Other moulds made of copper and cement were soon introduced as the trade became more resilient. Metal moulds were the first to be introduced after the "fish matter" type. These were already in use by I92I though probably not on a large scale. "Metal dies are apparently not common", stated a report of that year, "but a copper die has been found at Ijebu-Igbo and another of metal at Ijebu-Ode" ${ }^{34}$ By the I93os, the use of the copper mould had become widespread. In May 1933, the police found in the possession of one Salami "a copper mould adapted to make the resemblance of both sides of a French one franc piece, (and) a plain copper mould the size of a French one franc piece" ${ }^{35}$ In time, copper moulds were even made for sale, the price of one impounded by the police in 1937 being $£ 5 .{ }^{36}$ This meant that the technology was now widely diffused, an important development noted by the police: "some years ago[,] only very few people knew how to make moulds and these people guarded their secret too closely to be caught [but] [...] these days the art has spread and many people manufacture them, in fact each gang makes their own". ${ }^{37}$ The "democratization" of currency counterfeiting was aggravated by the recourse to cement moulds, which were easier and cheaper to make.

Cement moulds made their debut in the mid-1930s according to reports from the Ijebu and Oyo provinces. The Assistant Commissioner of Police in Ijebu-Ode informed the Resident of the Ijebu Province that the Ijebu were making "a new type of mould", consisting of "cement in a wooden frame". It had spaces for making a number of coins at one casting and could only be used once. This did not matter as the moulds were cheap and comparatively easy to make. The report claimed that the exhibit was "the first of its kind in this Province".$^{38}$ Also in May 1936, the District Officer of the Ife/Ilesha Division of the Oyo Province reported the discovery of "a new type of cement mould", the operation of which he described in detail. It consisted of:

[...] two wood frames, hinged so that they are open or close on to each other like

33. NAI CSO 20/9 NC 75/192I, Acting Resident, Ijebu to CSG, 3 April 192I. This corrects the claim (Falola, "Currency Forgery", p. I30) that the process of counterfeiting was not documented. 34. NAI IjeProf 2 C.I2, vol. I, Acting Resident, Ijebu to SSP, 3 April I92I.

35. NAI CSO 26/I 03447, "Re: Counterfeiting of French West African Notes", IGP to CSG, 29 October 1934 .

36. NAI IjeProf 2 C.I2, vol. 3, Assistant Superintendent of Police (ASP) to Resident, Ijebu, 2 July 1937 .

37. Ibid., vol. 2, memo. enclosed in ACP to Resident, Ijebu, 2 July 1936.

38. Ibid. 
an open and shut book, these frames are then filled with fine cement and genuine coins are laid in a row on one side and joined by a "gutter", the frame is then closed and when the cement hardens it is opened and the coins removed leaving a double impression on each side of the frame, the frame is then closed and the molten metal poured down the gutter filling the various impressions, when cool it is opened and produces a string of quite good counterfeit coins joined together by the metal strip which remains in the gutter, the coins are then separated and finished by hand. ${ }^{39}$

The advent of the cement mould had serious implications for the practice of counterfeiting. As the DO lamented, it made the act more prevalent, for, "any one $[s i c]$ with a rudimentary knowledge of carpentry and a bag of cement can make [...] [counterfeit coins]". By the new development, "the would be counterfeiter no longer has to obtain special impressions in metal before he can start work". The consequence was that counterfeiting had now become "prevalent on the Ilesha-Ekiti border" ${ }^{40}$ This was also buttressed by a police report from the Ijebu Province: "The ease with which cement moulds are made as compared with the old type of copper or white metal moulds doubtless has some bearing on the increase [...]". ${ }^{41}$

The counterfeiters selected a limited number of denominations of coinage for imitation. These would appear to be those which were either easier to counterfeit or more likely to bring profit given their higher values. Most prone to imitation were the English and West African alloy shillings and 2-shilling pieces. ${ }^{42}$

Expectedly, the initial coins produced by the forgers were of relatively poor quality. A report of July 1929 stated that some of the counterfeit 2-shilling pieces passed over the United Africa Company (UAC) counter in Benin were "not particularly clever imitations of the real thing" ${ }^{43}$ The "ring" and the milling betrayed these counterfeit coins. A I9I7 report by a police chief in Lokoja, northern Nigeria, noted that they lacked a "ring" and were characterized by their "uneven thickness and by a faint line running round the edge parallel to the surface suggesting that they were plates 'sweated' together" ${ }^{44}$ Many of these were easily detected for, as a police report noted, the "implements and appliances used by the coiners have always been found to consist of very primitive improvisations". ${ }^{45}$ As late as 1936, the police could claim that counterfeiters always found "the milling the most difficult part of the coin to reproduce and it is by milling that the doubtful coins are detected". The police contended that if it were possible for them to

39. NAI OyoProf I 1592, vol. I, DO Ife/Ilesha to Resident, 22 June 1936.

40. Ibid., DO to Resident, I4 July 1936.

4I. NAI IjeProf 2 C.I2, vol. 3, ACP to Resident, Ijebu, 6 October 1936.

42. Ibid., vol. I, Acting Resident to SSP, 3 April I92I.

43. NAI CSO 26/1 03447, ACP to IGP, Southern Provinces, Lagos, 23 July 1929.

44. NAK SNP 17/2 I3258, ACP, Lokoja to IGP, Kaduna, 25 January 1917.

45. NAI IjeProf 2 C.I2, vol. I, IGP to Treasurer, 9 December 1929. 
Table I. Composition of counterfeit and genuine florin (2-shilling piece) I929

\begin{tabular}{l|c|c}
\hline & Counterfeit & Genuine 1926 florin \\
\hline Weight of coins (grains) & 159.416 & (1) 174.154 (2) 175.342 \\
Number of millings & 131 & (1) 145 (2) 145 \\
Percentage of metallic content: & 61.4 & 3 d piece 1920: \\
Copper & 20.1 & 8.7 \\
Zinc & 12.8 & -1.1 \\
Aluminium & 0.8 & - \\
Tin & 3.3 & 100.1 \\
Lead & 1.6 & Yellow \\
Carbon, Oxide, Oxygen etc. by difference & 100.0 & Yellow \\
Total & Very pale & \\
Colour (a) Surface gilt & & \\
(b) Actual metal &
\end{tabular}

Remarks: The counterfeit contained a certain amount of air holes.

Source: NAI, CSO 26/I 03447, "Counterfeit Coins", Report of an Analysis by A.B. Hobson, Government Analyst, Lagos, dated 8 August 1929.

secure a machine to reproduce the milling "in a perfect form many of the counterfeit coins would never be detected by ordinary visual examination" ${ }^{46}$ This was an attestation of the level of the Africans' workmanship which, however, remained imperfect. An analysis of the composition of the genuine and counterfeit coins made by the government analyst in 1929, provided in the table above, revealed that the difference between the genuine and counterfeit coins was insignificant.

Attempts were, therefore, made by the counterfeiters to improve the quality of their products to evade detection. First, as noted above, rough edges were removed by a blow pipe and a steel file was used to give the coins a milled edge. Second, a mixture of chemicals consisting of ammonium and chloride was used to colour counterfeits so they could be like alloy coins. "The result", a report noted, "is much more convincing than the imitations of the silver coins". Consequently, counterfeit alloy coins tended to be in greater circulation than silver "owing to the varied colour of the alloy when it has been in use for some time" ${ }^{47}$ Counterfeiters took advantage of this to utter their product as worn genuine coins!

A gradual improvement then took place to the point that by the mid-I920s, the colonial government was in a state of near-panic. Governor Hugh Clifford reported to the Secretary of State for the Colonies in 1925 that:

$[\ldots]$ there is abundant evidence [...] to show that the offence of making and uttering counterfeit coin - especially the mixed metal coin - is greatly on the increase;

47. Ibid., vol. I, Acting Resident to SSP, 3 April I92I. 
[...] the coining is skillfully performed by experts with well-made moulds, proper instruments and proper material; and the business is systematically organized and energetically carried out. ${ }^{48}$

Colonial officials increasingly testified to the improvement in quality, as counterfeit coins proved more difficult to detect as the decade wore on. When counterfeit coins to the value of $\mathfrak{s}_{5}$ were detected in Kabba Province, northern Nigeria, in 1929, they were found to be "remarkably good imitations", and the man who had been paid in them was freed on this score, having received them as genuine in good faith. ${ }^{49}$ The Resident, Sokoto Province, testified in 1930 that "the counterfeiters have been most extraordinarily skilful in preserving the 'ring' of the genuine coin. I have tested every one of these coins and their ring is the same as that of an ordinary alloy coin". ${ }^{\text {so }}$ The police in Oyo Province admitted in 1936 that there was "an improvement in the making of the bad coin including the milling". ${ }^{\mathrm{SI}}$ It was thus implied that counterfeiters were achieving a measure of success in uttering the counterfeits. This leads us to the related issue of how the counterfeits were introduced into the economy.

\section{THE UTTERING AND CIRCULATION OF COUNTERFEIT CURRENCY}

The uttering of counterfeits, the criminal act of passing them off as genuine, was the complement of the art of counterfeiting itself. Oral and written evidence confirms that the makers and utterers of counterfeits necessarily shared risks and profits in the clandestine business. The Yoruba saying "asoro na bi owo Ijebu", (literally, "as difficult to spend as Ijebu money") indicates the magnitude of the difficulties faced by those uttering counterfeit money. ${ }^{52}$ This underscores the key element of trust that underlay the entire arrangement. The agreed sharing formula was 50 per cent for either party, in view of the great risks involved. ${ }^{53}$ Thereafter, the coins were introduced in any of the following ways.

First, utterers took advantage of night markets to introduce the fake coins into circulation with minimal risks of detection. This was prevalent in the Ilorin and Oyo Provinces, where night markets had been a long-standing way of life. As early as 1906, the Resident of the former had indicted southern Nigerians ("Lagos men") of spending counterfeit coins in night

\footnotetext{
48. NAI CSO I/32/78 iI2, of 6 February 1925, Clifford to Amery.

49. NAI CSO 26/I 03447, "Kabba Province, Nigeria: Intelligence Report for quarter ending 30 September 1929", by E.V. Rochfort Rae, Acting Resident.

50. NAI IjeProf 2 C.I2, vol. I, Resident, Sokoto to Resident, Ijebu, 26 September 1930.

5I. NAI OyoProf I I592, vol. I, ACP(Oyo-Ondo) to IGP, Lagos, I3 June 1936.

52. Oral evidence: Iperu and Ijebu-Igbo, 1998.

53. Ibid; corroborated in NAI IjeProf 2 C.I2, vol. 3, ASP, Ijebu-Ode to Resident, Ijebu, 2 July I937.
} 
markets in Ilorin. ${ }^{54}$ His counterpart in Oyo noted in July 1936 that "as most markets in this Province are held after dark, I have no doubt that a fairly large quantity of bad coin is in circulation, which stays in these markets, and is not tendered to Firms and Banks in the day light". ${ }^{55}$ Second, the counterfeit coins were included in tax proceeds. As we shall see, attempts were made to trace the coins to their source, that is, specific villages, or to hold tax collectors responsible for them! There was, on the whole, an avalanche of reports of bad coins turning up in tax collections all over the country. ${ }^{56}$ Third, the coins were spent in business transactions involving commercial firms and banks. Many of these were carried out in good faith by innocent people who had been duped in earlier transactions. But the case of a Nigerian clerk of the United Africa Company (UAC) who colluded with one Sam Eke to accept payment for Ioo cases of petrol worth $£ 160$ in counterfeit 2-shilling coins was the most spectacular. ${ }^{57}$ The fourth and perhaps the most successful means of uttering counterfeits was the cattle trade with northern Nigeria.

As early as I92I, the acting Resident of the Ijebu Province had reported that "the greater part of these coins are sent up north with Jebu cattle dealers, and [...] amongst the chief distributors are the servants of a rich Jebu cattle dealer named Salawu".$^{58} \mathrm{He}$ admitted, however, that the complicity of the latter had not been proven. Nevertheless, in a report of 1930, the Resident restated the claim of uttering via the northern route: "it is an established fact that the greater proportion (of the coins) is disposed of elsewhere, and it is suspected that the bulk is taken North by Ijebu cattle buyers, who are more active and numerous than I expected".59 $\mathrm{He}$, therefore, enjoined his counterpart in Kano to ensure that the Ijebu were caught red-handed, so that their source of supply could be uncovered. In further correspondence with the Resident, Sokoto Province, in whose domain some arrests had been made, he declared that the "favourite method of uttering is through Jebu cattle drovers who visit the Northern Provinces, often accompanied by local Hausa butcher boys of bad character". These men, it was stated, purchased cattle "with spurious coin, which is not easily detected or even suspected by the Northern cattle owners". ${ }^{60}$

From the foregoing, it is clear that the currency counterfeiting business

54. NAK SNP 6/2 II7/1906, extract from Report No. 32 [...] by Resident, Ilorin.

55. NAI OyoProf I I592, vol. I, Resident, Oyo to SSP, Enugu, I7 July 1936.

56. See, for example, NAK SNP I7/2 I3258, Resident, Kabba to CSG, Zungeru, reply to letter of 2 November 1913; and Rae, Asst. DO to Resident, Niger Province, Bida, 29 September 1917.

57. Details in NAI CSO 26/I 03447, Supervising Agent, UAC to CSG, I June 1929; Acting Resident, Benin Province to SSP, I2 June I929; Resident, Warri Province to SSP, 4 July 1929; and ACP to IGP, 23 July 1929.

58. NAI CSO 20/9 NC75/1921, Acting Resident, Ijebu to CSG, Lagos, 3 April 1921.

59. NAI IjeProf 2 C.I2, vol. I, Resident, Ijebu to Residents, Kano, Zaria and Sokoto Provinces, 9 February 1930.

6o. Ibid., Resident, Ijebu to Resident, Sokoto, Io October 1930. 
Table 2. Proportion of counterfeit coinage in official commercial transactions, 1936

\begin{tabular}{l|c|c}
\hline Firm & Amount paid in $£$ & Counterfeit coin in $£ \mathrm{sd}$ \\
\hline Barclays Bank & 6,100 & 6.18 .6 \\
October & 7,300 & 6.10 .5 \\
November & 1,200 & 0.3 .0 \\
John Holts Ltd. & 1,200 & 0.4 .0 \\
October & 300 & 0.14 .0 \\
November & 300 & Nil \\
G.L. Gaiser & 5,000 & 1.7 .6 \\
October & & 1.3 .0 \\
November & 900 & \\
United Africa Company & & \\
October & UAC Motors &
\end{tabular}

*Figures obtained from the BBWA, Lagos.

Source: NAI, Ijeprof 2 C.I2 vol. 3, Acting Resident, Ijebu Province to Secretary, Southern Provinces, Enugu, 5 December 1936. Cf. Falola, "Currency Forgery", pp. I24-I25, Table I.

was widespread, and that it caused panic in official circles. However, in terms of the official statistics, the volume of counterfeit coins was insignificant compared to the total amount of money in circulation at this time. The figures supplied in Table 2 in 1936 by Barclays Bank and the leading firms are revealing. By way of extrapolation, it could be suggested that there was possibly over one per cent counterfeit coinage in the total volume of money in circulation during this period.

Yet, one must concede that a certain proportion of the counterfeits must have evaded detection, particularly in transactions that did not involve the banks, commercial houses, post offices and the treasury. For, then as today, much of these was conducted through private or nonofficial channels. It was thus possible for counterfeits to have remained in circulation beyond the pale of officialdom, especially in the more remote communities. Even in Ijebu-Ode, the headquarters of the Ijebu Province, it was claimed in 1935 that "as much as $£_{1}, 500$ to $£_{2}, 000$ in counterfeit coins is in circulation" ${ }^{61}$

The colonial government reacted vigorously to the wave of currency counterfeiting in the interwar years. Its countermeasures ranged from police investigation, prosecution, propaganda, restriction of imports of items that were considered prone to use by counterfeiters, monitoring of parcels sent through the post, penalization of tax collectors, enactment of legislation, and international cooperation, to the introduction of security-edged coin-

6r. NAI IjeProf 2 C.I2, vol. 2, Acting Resident, Ijebu, 22 September 1935. 
age. These are considered in greater detail below. We should note that these approaches were combined rather than used in isolation.

\section{OFFICIAL RESPONSES TO CURRENCY COUNTERFEITING}

Realizing that the local populace had to be placed on the alert and involved in the campaign, officials embarked on propaganda to win their support. For example, the Resident of the Oyo Province issued a proclamation to be read out in all native courts at every sitting and pasted on the court notice board. It was also to be translated into the indigenous language. In it, heads of families, villages and towns were enjoined to report all cases of counterfeiting to olopa or akoda (police). ${ }^{62}$ The Secretary, Southern Provinces had also itemized the following points to be addressed by the anticounterfeiting propaganda.

First, the people were to know that the government viewed the offence "with extreme gravity". Hence, it had imposed a maximum penalty, under the Criminal Code, of life imprisonment. Second, counterfeiting should be seen as "a serious offence against the community". The coin was useless for the payment of tax, court fees and fines, and for the purchase of goods. Its existence led to people suspecting one another of attempting to pass bad money, and to a general lack of confidence in all transactions involving the use of coinage. Third, native authorities (that is, the local rulers) must make special exertions and warn their people of the danger in trafficking in counterfeit coins. They were to urge their subjects to dissuade their friends and relations from involvement in "this evil business, and exposing themselves to the danger of long terms of imprisonment". ${ }^{63}$ This was a clever exploitation of the general opprobrium attached to imprisonment in Yorubaland.

Propaganda produced mixed responses. On the one hand, it succeeded in sensitizing the populace to the menace of counterfeits, for many had accepted them ignorantly in commercial transactions to their economic ruin. Hence, people were now more painstaking in scrutinizing any coin tendered in the markets. The police chief in Ijebu Ode noted, in 1937, that "the market woman is an adept at discovering bad coin and in fact nearly every coin [...] is scrutinised before being accepted" ${ }^{64}$ Expatriate firms supported the campaign; the Kano Chamber of Commerce enjoined its members to assist "by exercising great care in accepting money over the counter". It advised them to constantly "be on the look out". ${ }^{65}$ On the other hand,

62. Ibid., Resident, Oyo to Bale and Council, Ibadan, 5 September 1935.

63. Ibid., SSP, Enugu to Resident, Oyo, 20 September 1935.

64. NAI IjeProf 2 C.I2, vol. 3, ASP, Ijebu-Ode to Resident, Ijebu, 2 July 1937.

65. NAK SNP 17/2 I4769, vol. I, "Kano Chamber of Commerce: Minutes of Meetings", Meetings of I2 May 1932 and I4 September 1933. 
the campaign did not elicit the expected cooperation from the traditional rulers of the people. The acting Resident of the Ijebu Province remarked that "there is a certain reticence noticeable amongst the Chiefs which it is difficult to explain. Information invariably comes to the Police through informers and not through the Chiefs as one should expect." ${ }^{\text {66 }}$ It can be inferred that they detested being turned into police informers, a despicable assignment unbecoming of their position in society.

As propaganda alone could not have checked the illicit practice, it was complemented by direct action. First, postal traffic was monitored and all parcels were scrutinized. This yielded fruit, as moulds and materials that could be used to counterfeit currency were intercepted. In a celebrated example, the recipient was tricked into collecting his parcel at the post office where he was arrested. ${ }^{67}$ Second, restrictions were placed on the importation of items that could be used to counterfeit currency, such as copper. ${ }^{68}$ Third, as an increasingly large amount of counterfeits turned up in tax proceeds, it was decided that the traditional rulers and, even, the colonial officials who had taken them in, should be liable for any proportion that was counterfeit! This was to make tax collectors more efficient in detecting bad coins. But this harsh method was promptly protested against by officials. The official in charge of the Lagos District acknowledged in 193I that "a fairly large amount of counterfeit coin" was in circulation in his area and much of it found its way into the Treasury "without being detected". As the counterfeit was often "extremely difficult to detect", he considered it "a hardship on the tax clerk and myself to have to make good these amounts when we are making every endeavour to get the tax in up to date". ${ }^{69}$

This plea was to no avail, as a 1936 circular directed all Residents in the southern provinces to make all receiving officers fully responsible for counterfeit coins in their tax collections. However, each case was to be considered on its merit, and reprieve would be granted if the counterfeit coin was a near-perfect imitation. Even so, counterfeits were to be destroyed in the presence of those who remitted them or their representatives. Tax collectors were told not to mix returns from different communities, so that counterfeits could be traced to their source. ${ }^{70}$ The Commissioner of the Lagos Colony, however, highlighted the extenuating circumstances to be

66. NAI IjeProf 2 C.I2, vol. 2, Acting Resident, Ijebu to SSP, Enugu, 2 July 1936. Ironically, Awujale Adenuga attempted to get rid of a political opponent by framing him as a counterfeiter. This backfired, as the incident provided the occasion for his deposition in 1929. See Ayandele, The Ijebu of Yorubaland, pp. 86-87. It is disappointing that this is the only reference to this burning issue in the entire book!

67. Nigerian Pioneer, 17 October 1924, Police News.

68. NAI Ije Prof 2 C.I2, vol. 2, Acting Resident, Ijebu to SSP, Enugu, 22 September, 1935.

69. NAI Comcol I 1279, "Counterfeit Coins", Assistant DO, Lagos District to DO, Lagos, 25 September I93I.

70. Ibid., SSP to all Residents, 3 November 1936. 
considered in the case of tax collectors in the Epe district, for example. First, the quality of the counterfeits was quite high, and so could mislead the most diligent of officials. Second, being located adjacent to "recognised counterfeiting areas" (that is, the Ijebu Province), the district was particularly prone to infiltration. Third, the amount of counterfeits discovered in tax collected was still within reasonable limits. He, therefore, recommended that the District Officer's liability be limited to half the amount of the counterfeits, the balance being written off. It was on this basis that a lenient view was taken and full refund made to the officer. ${ }^{71}$

By far the most celebrated method of dealing with the problem was the combination of police investigation, enactment and litigation. One of the methods of investigation and the apprehension of suspects was to "watch and search for suspects, particularly in those districts in which counterfeit coins circulate or are known to originate from, and also for the source of supply of their appliances and metals".$^{72}$ This yielded results, though the element of chance proved helpful. On one occasion, counterfeiters were caught when police were searching lorries on the Shagamu road for tax evaders. Two men inside a lorry were found carrying metals associated with illegal coining. The policeman detained them on suspicion for the night and they later reportedly admitted their guilt. When their residence at Iperu was searched, incriminating materials, including coins and moulds, were found. ${ }^{73}$

The police also employed informers, who were not always reliable. Their unreliability is expressed in the following comment by an official:

[...] our informants, following a well established custom of the Jebus, have been at pains to see that those incriminated should receive due warning when arrest was imminent. No small merit is thereby acquired in both camps. [...] The general result is that conviction for actual counterfeiting is usually avoided by the timely removal of all necessary material. ${ }^{74}$

But there were exceptions, for, much of the success achieved by the police was owed to timely tip-offs. In that event, suspects were placed under surveillance, as in the case of Sani Gegele, who practised his art in Ibadan, and Ijebu-Ode, until they were caught in the act. ${ }^{75}$ Police raids often took place at dawn, as early as 2 a.m., as exemplified by the raid on Daini Olatunde Bello, described by the police as "a notorious maker of counterfeit coins".

7I. Ibid., Commissioner of the Lagos Colony (COMCOL) to Financial Secretary, Lagos, 8 April 1938; Financial Secretary to COMCOL, 25 July 1938.

72. NAI IjeProf 2 C.I2, vol. I, Confid. I/I926: Rex vs Salami Temiyemi.

73. Ibid., Report by Acting DO, Ijebu-Ode, 23 April 1926.

74. NAI CSO 20/9 NC75/1921, Acting Resident, Ijebu to CSG, Lagos, 3 April I92I. This also implies that the counterfeiters had some form of implicit support in their "war" against the colonial state.

75. Ibid., Acting Commissioner of Police, Western Division, Ibadan to IGP, Lagos, enclosed in SSP to CSG, Lagos, 2 November I92I. 
On that occasion, seven persons were caught red-handed and a large quantity of incriminating evidence found in the room. ${ }^{76}$

But police action was not an unqualified success. Often the criminals got wind of their impending arrest and got rid of any incriminating evidence. As already mentioned above, informers were often unreliable as they played both ends against the middle. Moreover, in places like Ijebu Waterside, the difficulty of the terrain made surprise visits impossible. Criminals had advance warning of the approach of police launches and so could not be apprehended in the act. Sometimes, as the police admitted, the suspects offered stiff resistance. ${ }^{77}$

The police on their part were often incompetent or corrupt. Native authority police (akodas) appear to have been the worst culprits. In reply to a request for more Nigeria police personnel, the Commissioner (CID) Lagos noted that counterfeiting was most prevalent in areas which were "not directly controlled by the Nigerian Police and [...] owing to lack of training and knowledge of Police Duties the methods of the Native Administration Olopas are inadequate to cope with the present state of affairs" ${ }^{78}$ Corrupt policemen often concealed the offence, as was the case in Ilesha when four native authority policemen (akoda) were arrested on charges of taking bribes, so that they would not report offenders. Cases of blackmail were also reported, whereby police extorted from $£_{2}$ Ios to $£_{20}$ from people who did not wish to be incriminated! ${ }^{79}$

Another constraint faced by the police was understaffing, as they were too few to effectively cover such large provinces as Ijebu and Oyo. The acting Resident, Ijebu Province, provided a clear picture of the situation in the following report:

There is little doubt that the Ijebu Province is the centre of counterfeiting and the careful and prolonged investigation necessary in such case cannot be carried out by the Administrative staff at their present strength. The police are in charge of a junior and inexperienced Corporal who is incapable of undertaking any serious investigation $[\ldots] .{ }^{80}$

The head of the Nigeria Police in Ondo and Oyo Provinces bemoaned the lack of sufficient men for the job. "The only solution, at present", he declared, "would seem to be the posting of CID men to Ife and Ilesha and the employment of reliable agents". He, therefore, requested an increase in the personnel of the "I" Branch at Ibadan so that the men could be posted for fixed periods to various districts in the Ondo-Oyo Police Province to

76. Nigerian Pioneer, 17 October 1924, Police News.

77. NAI IjeProf 2 C.I2, vol. 3, Commissioner of Police (COMPOL) to Resident, Ijebu, 28 November 1936.

78. NAI OyoProf I I592, vol. I, Commissioner, CID, Lagos to ASP, Ibadan, 2 July 1937.

79. Ibid., Acting DO(Ife/Ilesha Division) to Resident, Oyo, I7 April 1937.

80. NAI IjeProf 2 C.I2, vol. 2, Acting Resident, Ijebu to SSP, 22 September 1935. 
deal with cases of counterfeiting and illicit distillation. Though his request was granted, he was told that such an increase would not permanently check the incidence of counterfeiting. ${ }^{81}$

Prosecution was the logical outcome of police investigations. But not all suspects were convicted. Convicts were sentenced to terms of imprisonment, ranging between five and fourteen years with hard labour, and flogging. As it was not always possible to apprehend the coiners in the act, guilt had to be determined in such a way that utterers could be distinguished from innocent victims of a swindle. Hence, Section 3 of the Criminal Code (Amendment) Ordinance 1938 (No. 40 of 1938) stipulated that anyone found in possession of ten or more unfinished counterfeit coins should be presumed to have made or been a participant in the act of making them, unless he could prove to the contrary. ${ }^{82}$ But opinion was soon divided among officials as to the appropriate penalty to be inflicted on convicts.

One school of thought held that stiff sentences would be a sufficient deterrent. An exponent of this position declared that this "will give some indication of the seriousness and severity with which such offences are being treated locally". ${ }^{83}$ This view prevailed until the mid-r930s. As the offence persisted, sentences were increased until the routine penalty was fourteen years' imprisonment, passed by the Resident and confirmed by the Secretary, Southern Provinces (SSP). Sentences also varied according to degree of culpability. Thus, in I92I Sani Gegele got ten years, his accomplice Amoosah (Amusa) was sentenced to three years' imprisonment, and Sam Eke in 1929 was jailed for seven years. ${ }^{84}$

By the mid-I930s, however, confirming officers began to reduce the stiff sentences. When in 1933, the Resident, Ijebu Province passed a sentence of fourteen years, it was not confirmed by the Governor, Donald Cameron. Reducing the sentence by half, he explained that he had never heard of a sentence that high for currency counterfeiting. The Resident, however, robustly defended his sentences on the grounds that they were to act as a deterrent and to "safeguard Society from the activities of such pests for a considerable number of years". He viewed with concern the reduction of the sentences, which, he felt, would lead the Ijebu to the conclusion that "offences against the Currency are no longer viewed as seriously as they have been in the past". He added that "[i]t should be remembered that Ijebu is the cradle of the local counterfeit coining industry" ${ }^{85}$ That heavy sentencing was the proper thing to do, he added, was confirmed by the remark of Captain N.S. Mansergh, Head of the Gold Coast CID, that "the

8I. NAI OyoProf I I592, vol. I, SP to COMPOL, Lagos, 4 June 1937.

82. NAI CSO I/32/I46 283 of 3 March 1939 , Bourdillon to MacDonald.

83. NAI IjeProf 2 C.I2, vol. I, Resident, Ijebu to Resident, Sokoto, 29 October I93I.

84. NAI CSO 20/9 NC75/192I, enclosed in SSP to CSG, Lagos, 2 November I92I.

85. NAI IjeProf 2 C.I2, vol. I, Chief Registrar, Lagos to Resident, Ijebu, 25 September I933;

Resident to Registrar, Io October 1933. 
officers in the Ijebu Province seem to be the only ones who know how to deal with the matter properly and give sentences which will help to stamp it out". Moreover, his counterpart in Sokoto Province in I93I had sentenced two Ijebu men who had been coining at Gusau to fourteen years' imprisonment with hard labour.

The severity of the punishment does not seem to have deterred prospective offenders. The observation of the Commissioner of Police in 1936 is very illuminating: "There would appear to be little change in the number of persons engaged in this crime, and from the information received neither the remarks from the Bench, the sentences imposed nor the activities of the Anti-Counterfeiting League would appear to have had any effect. ${ }^{\prime 86}$ As the I930s wore on, counterfeiting became rife, causing panic in official circles. Officials were frustrated by the realization that only those they described as minions were being jailed. "A disturbing feature of these prosecutions", noted an official, "is that the persons prosecuted are obviously the 'small' men. ${ }^{\prime 7}$ This prompted the "big man theory" which held that there was a mastermind behind the operations, "some Ijebu head counterfeiter or cattle dealer engaged in uttering" ${ }^{88}$ This theory was buttressed by the ability of coiners to introduce the counterfeits into circulation despite the enormous odds against them. It was, therefore, speculated that the mastermind must be "a man of standing [...] with trading interests and connections outside the Province, probably Northern Nigeria, who could mix the spurious coins with genuine coins and use the mixed bags for purchasing cattle and ground nuts". 89

The only thing that cast doubt on this theory was the fact that none of the suspects ever mentioned the name of any person of standing in society as the mastermind behind the offence. This struck the police as "a strange fact when the Ijebu character is taken into consideration and the readiness with which they implicate their friend and even their relations in an attempt to get out of trouble". ${ }^{\circ}$ This officer failed to consider the possibility that the criminals had taken oaths of secrecy, known among the Yoruba as "imule", akin to the "omerta" among Italian criminal gangs. This cannot be dismissed with a wave of the hand, considering the general belief in the potency of such oaths. Whoever betrayed his partners became "odale", literally, betrayer of the Earth, a serious form of treachery. Hence, the Yoruba saying: "eni dale a ba'le lo", literally, "the Earth will swallow its betrayer".

International action by the League of Nations and the colonial powers (the French and British in this case) also attempted to curtail the traffic in counterfeit currency. The League even organized an international confer-

86. Ibid., vol. 3, COMPOL to Resident, Ijebu, 28 November 1936.

87. Ibid., vol. 2, Acting Resident, Ijebu to SSP, Enugu, 2 July 1936.

88. Ibid., vol. I, Resident, Ijebu to Resident, Sokoto, 29 June I93I.

89. Ibid., vol. 2, ACP to Resident, n.d., enclosed in Resident, Ijebu to SSP, 2 July 1936.

90. Ibid., ACP to Resident, n.d. (1936). 
ence which adopted a convention to combat the menace. Although it did not prescribe punishments, Article 3 declared counterfeiting and uttering as "ordinary crimes" that must be punished. Article 5 stipulated that the same degree of severity should be meted to criminals whether they were forging local or foreign currencies. Article Io made counterfeiting an extraditable offence, while Article 12 recommended that a central coordinating office be set up in each country to carry out investigations into the crime. Articles 9 and 18 expected each nation to prosecute all offences "in conformity with the general rules of its domestic law" ${ }^{91}$ Intercolonial cooperation between the French in Dahomey and the British in Nigeria was also undertaken and each ensured that its territory was not used as a haven to counterfeit the currency of the other. ${ }^{92}$

As it became increasingly clear that the above methods could not stamp out counterfeiting, suggestions were made to introduce new coins that would be difficult to counterfeit. This opened a lively debate on the desirability of returning to silver coinage, which had been withdrawn from circulation in the 1920s. The Nigerian Pioneer had opined in 1927 that "a reversion made to silver" was the "only solution" to counterfeiting. ${ }^{93}$ The view was supported by S.H. Pearse, a leading African member of the Legislative Council, W.F. Becker of the Bank of British West Africa, and many businessmen. This call went unheeded in the 1920 because the Governor, Graeme Thomson, did not believe that the situation "had assumed such proportions as in itself to warrant the reintroduction of a silver subsidiary coinage". ${ }^{94}$

But the I930s witnessed great intensification of counterfeiting and prompted calls for a new coinage to replace the alloy that was relatively easy to forge. Noting that the amount of counterfeit coin in circulation was "disturbingly large", the Nigerian Currency Officer renewed the call for reversion to silver coinage..$^{95}$ The demand for change was also made by other officials, one of whom suggested that coins be made from stainless steel, since reversion to silver would reduce the currency board's profits considerably. ${ }^{96}$ Steel coins, he explained, would retain their colour and design, and should cost less than silver. Governor Bernard Bourdillon was not persuaded, for, as he argued, while the introduction of silver coinage would reduce forgery "very considerably", it would not stop it altogether. He

9I. Details in NAI CSO 26 23870, "International Convention for the Suppression of Counterfeit Currency".

92. NAK SNP 17/2 13258, Lieutenant Gouveneur du Dahomey, Porto Novo to Lieutenant Governor, Northern Nigeria, 7 September I9IO; C.L. Temple, Acting Governor to Governor General, French West Africa, 2 February i9II.

93. Nigerian Pioneer, 8 July 1927, "Rambling Notes and News".

94. NAI CSO I/32/82 236 of 20 March 1926 , Thomson to Amery.

95. NAI CSO I/34/40, Confid. 3 November 1936, Hunt to Ormsby-Gore.

96. NAI OyoProf I I592, vol. I, DO (Ife/Ilesha Div.) to Resident, Oyo I4 July 1936. 
contended that counterfeits were "by no means unknown when Nigeria had a silver currency". Though the situation was close to the danger point, he held that "the extreme and expensive step of changing currency" had not yet become necessary. ${ }^{97}$

The government in 1938 eventually introduced an alloy coin with a "security edge" to "render counterfeiting much more difficult". ${ }^{8}$ This seemed to have answered the prayer of a member of the Kano Chamber of Commerce who had suggested that a new currency be introduced which would be "more difficult to counterfeit". ${ }^{99}$ After all had been said and done, such expectations were frustrated. Bourdillon reported forlornly in 1939 that, despite the "security edge", "counterfeiting of the coins is already taking place [...]. They are being detected in increasing quantities" . ${ }^{100}$ This was the state of affairs when the Second World War broke out. Reports of counterfeiting then became rare, probably because the government was contending with far more serious threats. The inference from the silence in official records and in the newspapers is that the incidence of counterfeiting dropped sharply during and after the war. But that it persisted, or at any rate that the suspicion that it generated lingered, is indicated in reports of people refusing to accept worn coin which they considered counterfeit. ${ }^{\text {Ior }}$

\section{CONCLUSION}

Currency counterfeiting caused a major scare in official circles in Nigeria during the interwar years. It was a product of the peculiar circumstances of this period. On the one hand, there was a demand for cash generated by the imperatives of tax payment and commercial transactions in the monetarized colonial economy. On the other, there were the inadequacies in the currency system, especially shortage of supply, and loss of the colour of alloy coinage. Caught between these pressures, the colonial subjects had to chart a path of survival in an economy that placed a high premium on cash and accumulation. Counterfeiting was thus a means of shortcircuiting the colonial economic system for personal gain. It is clear from the evidence adduced in this paper that it was given a fillip by the economic adversity of this period. This, therefore, contradicts the assertion that "there seems to be no correlation between the performance of the economy (e.g., growth, depression, expansion, etc.) and counterfeiting". ${ }^{102}$

The role of the Ijebu, which was quite significant, needs to be explained beyond the reference to their proximity to the coast and their renowned

97. NAI CSO I/34/40, Confid. 3 November 1936, Hunt to MacDonald.

98. NAI CSO I/32/I42 576 of 20 June 1938, Hunt to MacDonald.

99. NAK SNP 17/2 I4769, vol. I, Minutes of meeting of I2 November 1937.

ıoo. NAI CSO I/34/44, Confid. is April 1939, Bourdillon to MacDonald.

ıоI. Daily Times (Lagos), 26 April ı950, Okubotin to Editor.

I02. Falola, "Currency Forgery," p. I24. 
business acumen. ${ }^{103}$ For they were no closer to the coast than the Awori or the Ilaje, who were not known for counterfeiting coins. Moreover, the Ijesha, who were also renowned traders, especially in eastern Yorubaland, did not participate in it to any great extent. Hence, we must seek additional explanation for this behaviour.

First, the world-view or societal aspirations of the Ijebu should be considered. It is worth noting that they place a high premium on accumulation of material wealth. This is not surprising, given their age-old participation in commerce from the precolonial era. Success in business from this era had always been acknowledged by the society. Little wonder that in the nineteenth century, trade was the key element in Ijebu external relations, on account of which they were involved in the Yoruba civil wars. Disputes over trade routes also led to their fatal clash with the British in I892. In the domestic sphere, no Ijebu would like to be a servant to another unless he could not help it, and the spirit of economic independence knew no bounds. The quest for wealth, economic independence and modernity were some of the forces driving Ijebu enterprise. Aronson commented that "among the Yoruba it was the Ijebu who had the most widespread, even notorious, reputation for involvement in and enthusiasm for 'modern' life". ${ }^{\text {IO4 }}$

The pursuit of wealth to achieve economic independence caused some of them, presumably those who could not acquire wealth by legitimate means, to put to criminal use the ingenuity that was acknowledged by colonial officials, and which often led paymasters to recruit them far from their homeland. ${ }^{\text {Ios }}$ Counterfeiting, a deliberate misapplication of the Ijebu genius, was thus primarily motivated by profit and accumulation, fuelled by the demands of a new order, encouraged by the society's premium on wealth, and facilitated by the practitioners' artisanal skills. A parallel can be drawnfrom Freund's study of tin miners on the Jos Plateau. He noted that "illicit mining has historically served as a means of capital accumulation for petty, and in their own way, parasitic entrepreneurs". ${ }^{\text {Io }}$

Second, the element of alienation and resistance should also be highlighted. As the Ijebu were the only Yoruba subgroup that offered stiff military resistance to the British, their prominence in the counterfeiting business can also be suggested as proof of alienation from, and resistance to, the new

I03. Ibid., p. I3I.

I04. Dan R. Aronson, The City is our Farm: Seven Migrant Ijebu Yoruba Families (Cambridge, MA, 1978), p. xix. The Ijebu love of money is said to be revealed by their offering sacrifice of pigs to Osaluga, deity of wealth. This is peculiar to them among the Yoruba. I owe this information to Dimeji Ajikobi, Lagos, January 2000.

I05. NAK SNP 17/2 13258, Resident, Katsina to SNP, I5 April 1938. The artisanal skill of the Ijebu is acknowledged by other Yoruba who describe them as "Omo a wo irin tun 'rin ro" (those capable of smelting and moulding metals into any object). I thank Dimeji Ajikobi for this information.

I06. William Freund, "Theft and Social Protest among the Tin Miners of Northern Nigeria", in Crummey, Banditry, p. 60. 
order. The theme of Ijebu alienation from, and resistance to, the colonial order has been pursued in a study of the Ijebu attitude to the colonial institutions of law and order. Rotimi has summarized it as one of "unwillingness to forgive and forget" as they refused for long to join the military and the Nigeria and native authority police forces. ${ }^{107} \mathrm{He}$ further noted that:

The Ijebu ruling elite [...] were co-opted into the colonial ruling machine. But the generality of brutalised Ijebu showed no enthusiasm about being colonised; they did not forgive or forget the rude interruption and subsequent subversion of the normal rhythm of their lives that the 1892 British expedition constituted. ${ }^{\text {I08 }}$

Ijebu resentment of the colonial order, expressed in their reluctance to enlist in the local police, and refusal to cooperate with non-indigenes who did, "echoed the memory of the 1892 expedition". ${ }^{\text {I09 }}$ Having been alienated from the new order, the Ijebu could only have seen the colonial economy as fair game that should be exploited for their own benefit without any feelings of guilt.

To be sure, they had economic grievances too. "Since the new currencies were scarce and the (colonial) people earned little for their goods", it has been contended, "the Ijebu exploited their skill in goldsmithing to make facsimiles of the new currencies" ${ }^{\text {II }}$ But they did not invent currency counterfeiting as a form of economic warfare. As Jenkins noted in respect of Anglo-French relations in the eighteenth century:

[...] unscrupulous business men in Britain [...] manufactured bogus coinage (of impure metal and inadequate weight) that imitated the money in use on Martinique: the offending currency was then shipped to the Caribbean "under the Description of wrought Iron". Even when the swindle was discovered, the Board of Trade had to seek legal advice before taking counter-measures - after all, it was not British money which had been counterfeited. ${ }^{\text {III }}$

Seen in the light of the above, Ijebu involvement in currency counterfeiting was a continuation of resistance by other means, following the failure of military confrontation with the British. Given their alienation from the new order, Ijebu coiners did not see their activity as the colonial government treated it: economic sabotage, a criminal act capable of ruining the colonial currency system. They rather regarded it as a legitimate means of accumulating wealth in the conditions created by resented alien rule. Consequently, currency counterfeiting by the Ijebu in colonial Nigeria combined elements of resistance to and accumulation in the new socioeconomic milieu. Relating this study to the discourse on "heroic criminals", the counterfeiters of colo-

107. Rotimi, "The Ijebu and the Police", pp. 98-105.

108. Ibid., p. 98.

I09. Ibid., p. I04.

IIO. Ibid., p. Iо2.

III. H.J.K. Jenkins, "Guadeloupe, Martinique and Commerce Raiding: Two Colonies in Conflict, 1797-1798”, Revue Française d'Histoire d'Outre-Mer, 78 (1991), p. 468. 
nial coinage in interwar Nigeria were no heroes. ${ }^{\mathrm{II} 2}$ They did not share their loot with the underprivileged. As petty crooks, they preyed on both the government and their fellow colonial subjects.

II2. This does not suggest that all Ijebu were counterfeiters, or that all counterfeiters were Ijebu. Yet, the popular association of the Ijebu with the crime is recorded even in a popular Yoruba song: "Ohun gbogbo n’Ijebu nse o: Ijebu ns'owo, Ijebu ns'omo" (literally, "Ijebu 'make' all things including money and babies"). I owe this information to Dr Kemi Rotimi, oral communication, London, November 1998. The Yoruba expression, "se owo", in this sense, denotes counterfeiting rather than "making money" in the ordinary business sense. 
